\title{
12. SEDIMENTOLOGICAL ASPECTS OF STRATA ENCOUNTERED ON LEG 23 IN THE NORTHERN ARABIAN SEA
}

\author{
Oscar E. Weser, Scripps Institution of Oceanography, La Jolla, California
}

\section{INTRODUCTION}

Hydrographically defined (Schott, 1935), the Arabian Sea roughly encompasses that part of the Indian Ocean which lies north of the equator and west of the Laccadive-Chagos Ridge. Its area of nearly 7,500,000 $\mathrm{km}^{2}$ comprises one-tenth of this ocean. Running diagonally across the Arabian Sea is a prominent subsea feature, the Carlsberg Ridge (Plate $1^{1}$ ) which divides it into a northern and southern part.

The six Leg 23 drill sites that were used to investigate the northern Arabian Sea (Sites 234 and 235 of Leg 24 were drilled in the southern half) have provided the first opportunity to study a significant part of the sedimentational history of this large area. Previous direct observations were limited in the time dimension by the depth of penetration of the piston core. Geographically, most of these observations were restricted to a scattering of control points, too few to draw any but gross generalizations regarding sediment distribution. Such generalizations can be seen on the maps of Lisitzin (1972), Fairbridge (redrawn by Spencer, E. W. after Schott, W., 1966) and Shepard (1963). More detailed work in portions of the northern Arabian Sea by Stackelberg (1972), Stewart et al. (1965), and Goldberg and Griffin (1970) obtained data for more refined studies. However, these studies provided only partial coverage either as regards the sum of the sediment components analyzed or of the area encompassed.

Indirect observations recorded by geophysical surveys penetrate much deeper stratigraphically, but any attempts to decipher sediment characterizations from this data are limited to making gross descriptions such as pelagic or terrigenous. The only age connotations which can be derived are the dating of those acoustostratigraphic horizons which intersect identifiable magnetic anomalies.

Admittedly, the DSDP Sites in this region, which are unequally spaced and widely separated, provide a miniscule sampling of the large volume of sediments in this area. Nevertheless, as subsequent discussion will show, the sites were propitiously located for the derivation of sedimentological conclusions in the intervals penetrated. In addition, the geological and geophysical data, and concepts which relate changing water depths to sea floor spreading, allow certain extrapolations to be made as to sediment types in intervals not sampled by the drill.

\footnotetext{
${ }^{1}$ Plate 1, entitled "Arabian Sea and Red Sea," is located in the pocket at the back of this Volume.
}

\section{GEOGRAPHIC SETTING}

Plate 1 shows the major bathymetric features of the northern Arabian Sea. Starting with the shelves, they together with their backdrop of landmass area provide a three-sided rim of sediment sources. Beginning along the southwestern shore of India, the shelf is only $60 \mathrm{~km}$ wide but rapidly broadens to the north where the high sediment input of the Indus River has constructed a 350-km-wide shelf off the Gulf of Cambay. Along the northern periphery of the basin, the shelf quickly narrows from a width of $150 \mathrm{~km}$ near Karachi to $40 \mathrm{~km}$ or less, a width which persists all the way to the Gulf of Oman. Along the western margin of this sea, shelf widths of the Arabian coast are normally even narrower. Along the Oman coast, the shelf is but a few kilometers wide. At a few places it widens to about $75 \mathrm{~km}$.

Most of the predominantly mud covered slopes meet the deep-sea floor at a depth of 3,000 meters. The slopes off the western coast of India have gentle dips of $2^{\circ}$ to $3^{\circ}$. Towards the north, the huge Indus Cone forms a continental rise along the lower slope, and the depth and contact between slope and basin is blurred. The slopes along the Iranian and Arabian coasts are much steeper and more irregular than the aforementioned ones.

A prominent submarine canyon, named "The Swatch", notches both slope and shelf off the mouth of the Indus River. Other, smaller canyons must cut the western, northern, and eastern slopes. Witness to this are the many abyssal plains which occur in the Arabian Sea plus the compositionally variable turbidites encountered on Leg 23 and by Stackelberg (1972). Unfortunately, bathymetric surveying to date is not sufficiently accurate to establish the location of all these conduits of deep-sea sediments along the slopes.

The basin areas beyond the continental slopes are basically the regions explored by the Leg 23 holes. Most prominent here is the Arabian Basin whose margins are formed by the Murray, Owen, Carlsberg, and Laccadive-Chagos ridges and by part of the western Indian continental margin. Each of the four ridges serves to separate this basin from adjoining ones. The Arabian Basin is divided on the basis of its surface slope into the Indus Cone to the north and the Arabian Abyssal Plain to the south.

The boundary between these two features occurs at about the 4,000-meter isobath, a depth which serves to split this basin into two almost equal parts. From the Glomar Challenger profiler record, the termination of the Arabian abyssal plain against the Carlsberg Ridge occurs near a depth of 4,700 meters (see $0130 \mathrm{hrs}$., 18 March, Figure 1, 
Plate 1). These same records indicate the presence of leveed channels on both the abyssal plain and the cone surface. Needless to say, they are more prominent and numerous on the latter surface (see the profiler record from 1800-2330 hrs., 23 March on Figure 2, Plate 1). Locally, the pelagically draped volcanic crustal floor of the basin; which was buried by the cone and abyssal plain deposits, contains topographic irregularities which do not resemble normal abyssal high topography. At 0400 hours, 21 March on Figure 3, Plate 1, this surface is shown as actually protruding above the level of the abyssal plain.

The Owen Ridge serves to separate the Arabian Basin from the Owen Basin. At one time, this ridge appears to have acted as a continuous topographic barrier between these two basins. However, continuing deposition along both sides has served to bury prominent gaps in this ridge and consequently has destroyed its continuity (see seismic record on Figure 4, Plate 1).

The Arabian Basin is separated from the Oman Basin to the north by the Murray Ridge. Although this ridge acts as a prominent continuous barrier, as sea floor contours on Plate 1 show, intermixing of bottom sediments between these basins could occur via spillage through the Owen Basin.

To the east, the Laccadive-Chagos Ridge is apparently an effective barrier against bottom sediment transport from the Laccadive Basin into the Arabian Basin (see Figure 5, Plate I). Finally, along its southern margin, the Arabian Basin has the Carlsberg Ridge as a prominent barrier to bottom sediment transport into the deeper Somali Basin. This ridge does have several deep gaps which run across it. Its deepest gap which occurs near the juncture with the Owen Fracture Zone, is at a depth of about 3400 meters. There the detailed bathymetric chart by Laughton et al. (1970) indicates that this gap forms a 600 - to 800 -meter high sill separating the two basins.

All the above mentioned basins, the Arabian, Owen, Oman, Laccadive and Somali, are extensively floored by the typical flat-floored relief of abyssal plains.

\section{CLIMATE AND CURRENTS}

Wind and weather play an important role in the current flow of the Arabian Sea as well as in the nature of the transport agents and their volume of sediment discharge in to this area. A monsoonal wind system prevails in this sea. This wind results in a typical low-latitude monsoonal surface current pattern which is characterized by summer and winter flow reversals accompanied by only small variations in surface temperature. During the southwest monsoon, which begins in the spring, the Somali Current in the western Arabian Sea is strengthened and becomes part of a general clockwise flow in this sea. Eventually upon reaching the tip of India, it flows eastward past Ceylon. It is during this period that pronounced upwelling takes place all along the Arabian coast and surface water temperatures drop $10^{\circ} \mathrm{C}$ or more. The effect of the weaker northeast monsoon reverses the flow to a counter clockwise direction north of the Indus River while that to the south of this river persists as a weak southerly (clockwise) flow. The latter, instead of flowing east, turns westerly thereby creating a current flow pattern more typical of a Trade
Wind system. Upwelling is now more localized, developing mostly in the northern regions off Karachi.

The energy generated by the monsoons extends beyond its influence on the wind-driven circulation as it is also translated into wave energy. This energy when coupled with tidal currents results in sediment transport at considerable water depths. Off the western Indian coast, Düing (1970) noted their effect on sediments down to 400 meters. This indicates that suspended matter is made available to far ranging shallow and intermediate depth water masses.

As relates to sediment transport, the monsoonal winds are the prime factor in the considerable influence of eolian sedimentation in the Arabian Sea. At times, exceptionally strong northeast winds blow dust from the Pakistani and northwestern Indian deserts. During the southwest summer monsoon, dust-laden air is derived from the Arabian and African deserts. Common summer dust storms also occur along the Makran coast of Pakistan and Iran (Stewart et al., 1965). The prevailing northwest winds in the region of the Persian Gulf provide a further source of eolian material. During the 1 month Leg 23 cruise of the Glomar Challenger in the Arabian Sea, the sky was noted to be continuously hazy

Climatic patterns over the landmasses surrounding the Arabian Sea provide significant controls for the kind and amount of sediment shed into this sea. Along its eastern margin, a humid climate provides the rainfall necessary for abundant river run-off. Although much of this run-off drains into the Bay of Bengal a sizable amount enters this sea via the Indus River. The northern and western margins are characterized by a desert climate, and there the sediment supply is relatively low and strongly influenced by eolian clastics. Some additional detritus is provided by intermittent streams and some by the formation of authigenic carbonates.

\section{WATER MASSES}

A diversity of sources contributes to the upper portion of the Arabian Sea thermohaline circulation pattern. High-salinity waters which pervade this region originate in the Red Sea, Persian Gulf, and northern Arabian Sea. Their flow extends from below a depth of 100 meters to approximately 900 meters.

Throughout much of the Indian Ocean, deep and bottom waters are generated in high latitude Antarctic regions, the Atlantic Ocean, and the equatorial region of the Indian Ocean. In the Arabian Sea, their influence on water masses is minimal as their limits of latitudinal flow normally do not extend that far north (Fairbridge et al., 1966 and Wyrtki, 1971.) Down to a depth of 1,500 meters, there appears to be a net outflow of North Indian Deep Water formed in the Arabian Sea from Red Sea Water and of water from the Gulf of Oman. From below this water mass to the sea floor not much is known concerning net inflow or outflow. Within this interval is found North Indian Bottom Water derived from the mixing of Antarctic Bottom Water and North Indian Deep Water. It is apparent, however, that the Carlsberg Ridge has a silling effect on the bottom waters of this sea. This is reflected in elevated bottom water temperatures (Defant, 1961 and Wyrtki, 1971) and by an examination of the sea floor isobaths 
(Laughton et al., 1970). There, the previously mentioned silling effect of this ridge serves as a barrier to the uninterrupted flow of bottom water (and also to bottom sediment transport).

\section{GEOCHEMISTRY OF SEAWATER}

No attempt will be made here to fully document the geochemical regime of the Arabian Sea. It is useful, however, to examine the oxygen content and the calcium carbonate compensation depth (CCD) as their influence on sediments can at times be observed in the stratigraphic record.

A formal study relating calcium carbonate dissolution to water depth in this sea has as yet not been made. Bszrukov (1961) noted the replacement of carbonate sediments by "red" clays at depths of 4,20 n to 4,700 or 5,000 meters at various stations in the Indian Ocean. These dissolution depths, which are in part dependent on bottom water temperatures, may not apply to the partly silled Arabian Sea. Detailed studies of the carbonate content of piston core sediments taken there at depths extending from 75 to 4,545 meters were made by Stackelberg (1972). At the latter depth, the carbonate content still averaged nearly 30 percent.

Except for a few small silled basins on the lower flank of the Carlsberg Ridge, water depths do not exceed 4,700 meters in the Arabian Sea. Consequently, one may say that for all practical purposes the complete solution of calcium carbonate does not occur in this sea (i.e., it is above the CCD).

Throughout much of the Indian Ocean, a shallow and a deep oxygen minimum are separated by an oxygen maximum. This configuration is lacking in the Arabian Sea, where the absence of the oxygen maximum results in a single oxygen minimum. Furthermore, the $\mathrm{O}_{2}$ content of this minimum reaches some of the lowest values found anywhere in the Indian Ocean. Wyrtki (1971) shows this minimum as extending between depths of about 100 to 1,500 meters. Oxygen content is usually less than $0.5 \mathrm{ml} / 1$ within this interval, ofttimes barely reaching the limits of detection. The work of Stackelberg (1972) on the east side of the Arabian Sea shows a zone of $0.5 \mathrm{ml} / 1$ oxygen, encompassing depths of 200 to 1,300 meters at Karachi in the north but only 150 to 700 at Cochin to the south. Below the oxygen minimum, the oxygen content shows a gradual increase so that most basin floor areas in the Arabian Sea are within well-oxygenated waters. Generally speaking, however, the Arabian Sea has proportionally less oxygen-rich waters than anywhere in the Indian Ocean.

\section{RECENT SEDIMENT SOURCES AND THEIR CHARACTERISTICS}

Present-day sediment sources are manifold in the Arabian Sea as shown by recent workers. Those of significance to this study are of fluvial, eolian, biogenous, and authigenic origin. Of the latter, only those available for resedimentation into deeper water are of concern here; consequently, nonresedimented (i.e., deep-water) authigenic constituents will not be dealt with.
Fluvial detritus is one of the major sources of Arabian Sea sediments. By far the largest contibutor is the Indus River with an annual suspended load of 440 million tons (Holeman, 1968). This load, largely derived from the Himalayas and the Indo-Gangetic plains, has constructed a large delta just south of Karachi. These deltaic sediments are probably somewhat mixed with coastal sediments from the north and south before being carried into deeper water. Of lesser importance along the Indian Coast is the Narbada and several smaller rivers which drain the Deccan Traps. It debouches into the Arabian Sea south of the Indus Delta in the Gulf of Cambay. All other Indian Rivers flow eastward into the Bay of Bengal. The arid regions adjoining the northern and western Arabian Sea have a low runoff, and the few minor rivers there provide a minimum of fluvial products.

As a consequence of strong, nearly year-round winds blowing off large desert areas, a considerable amount of eolian detritus is supplied to this sea. In the Persian Gulf, it was estimated by Sugden (1963) that possibly one-third of the sediments were of wind-borne origin. Calculations by Goldberg et al. (1970) suggested that 80 million tons of such sediments were annually being deposited in the Arabian Sea. Although most of it accumulates in the western portion, he presented data that some was still quite evident as far east as the deeper water region off the southwestern coast of India.

A variety of biogenous material is presently being supplied to this region. In shallow-water shelf regions, significant accumulations of mollusks, benthonic foraminifera, pteropods, and fecal pellets occur which then are redeposited into deeper water. Large portions of the outer Indian shelf are covered by such material (Stackelberg, 1972) as are some of the coral islands of the Laccadive-Chagos group. These islands are themselves a source of additional biogenous material in the form of reef debris. Schott (1966) indicates the nearshore presence of calcareous sand along the shelf and of foraminiferal sand slightly farther offshore, off the northeast coast of Africa. Little is known concerning the carbonate content of shelf areas in the northern and western Arabian Sea; however, on the basis of its occurrence in turbidites at Site 223, its presence there would not be surprising.

No doubt pelagic microfossils are quantitatively more significant than the biogenic contribution from shelf areas. The nutrient-rich upwelling waters of the eastern and western Arabian Sea serve to generate an abundant planktonic growth. Because, as previously shown, most of the sea floor is above the CCD a goodly portion of the fossil tests generated by this growth is preserved in the sediments.

Shallow-water authigenic minerals normally are not a significant admixture to deep-water sediments. However, later discussions will show this is not true for Leg 23. It is of interest that aragonitic oolites and needles are not uncommon in the Arabian Sea area. Oolites have been noted in the Persian Gulf by Sugden (1963), and Stackelberg (1972) found abundant white oolites and aragonitic needles along much of the western Indian shelf. Glauconite is not a common mineral in this region. Silt-sized dolomite grains, either as rare rhombs or rounded particles, were noted by Stewart, et al., (1965) in the 
northern Arabian Sea. They were also found by Goldberg and Griffin (1970) in both the northern and southern Arabian Sea.

\section{THE SOURCE AND DISTRIBUTION OF SOME CLAY MINERALS}

Surrounding the Arabian Sea are several major drainage areas which contain rocks whose erosion products give rise to unique clay mineral assemblages. Recognition of these assemblages in the Leg 23 strata allows identification of the sediment source areas. In one instance, a clay mineral even appears to be diagnostic of its transport agent.

Palygorskite, which was found in many Leg 23 Arabian Sea cores, can occur either as an authigenic or detrital mineral. As an authigenic mineral it is being found with increasing frequency in deep-sea pelagic sediments. Conditions favorable for its formation there requires the presence of excess silica in the sediment pore space. Such silica can be derived from the devitrification of volcanic ash or the solution of opaline fossil tests (Hathaway and Sachs, 1965). Sediments of that type are few in the Arabian Sea cores and therefore a detrital origin for most palygorskite occurrences is more reasonable. In this regard, Müller (1961) noted the presence of palygorskite in sediments of southern Arabia. Goldberg and Griffin (1970), who found it to be distributed in samples over the entire southern part of the Arabian Sea with a gradient of decreasing amounts from west to east, believe that it may also be derived from desert regions of North Africa (see Figure 1). Thus, palygorskite, in addition to pinpointing a source area, is at times an indicator of eolian transport.

The weathered Deccan Traps of western India provide a unique source of detrital clays having a high montmorillonite content for the eastern Arabian Sea, an aspect noted by many authors. There too, however, the possibility of a primary authigenic source must first be considered. The combination of conditions necessary for this type of formation appears to be slow depositional rates and a predominance of basic volcanics undergoing diagenetic alteration. Because these conditions did not exist at Sites 219 to 221 , this mode of origin can be ruled out for the southeastern Arabian Sea sites. The same is not true of Sites 223 and 224 in the northwestern Arabian Sea.

A third diagnostic source is provided by the clay mineral assemblage of the Indus River drainage. Sampling by Förstner (1971) near its mouth shows an illite-chlorite ratio of about $3: 2$. In addition, there is only a trace of montmorillonite, no palygorskite or kaolinite, and nearly 10 percent carbonate. Quite possibly, after it reaches the coastline, some montmorillonite is mixed into this clay assemblage by northward longshore transport as is illite by southerly currents. Perhaps a more accurate assessment of this clay mixture when it is finally transported away from the Indus delta is provided by the $<2 \mu$ fraction of the Indus Cone turbidites at Sites 221 and 222. They show an illite/chlorite ratio of 3 or 4 to 1 . The absolute amount of illite normally ranges from 30 to 50 percent and chlorite usually from 12 to 15 percent. Additionally, there commonly is 5 to 10 percent montmorillonite, little or no kaolin, and 20 to 24 percent quartz. The bulk X-ray analyses also reveal an 8 to 12 percent calcite content.

\section{HISTORY OF SEDIMENTATION IN THE ARABIAN SEA}

\section{Southeastern Area}

Although three sites were drilled in the southeastern Arabian Sea, only two, Sites 220 and 221, reflect directly on the history of the southern and southeastern Arabian Basin. Site 219, because of its location on the Laccadive-Chagos Ridge, records sedimentation on a structural element which had a differing behavior. Nevertheless, its proximity to this basin provides some insight as to paths and modes of sedimentation there as well as the history of the adjacent Indian landmass.

\section{Site 219}

After a penetration of 411 meters, Site 219 bottomed in Upper Paleocene sediments having an approximate age of 58 m.y. They strongly reflect nearshore shallow-water sedimentation, an aspect which persisted till the end of Paleocene time. Encompassing 147 meters of section, these sediments are typical shelf type green to black terrigenous sands, silts, and shales overlain successively by glauconitic limestones and foraminiferal sandstones, all apparently deposited at a rapid rate. This rate, which averages $>70$ $\mathrm{m} / \mathrm{m} . \mathrm{y}$., represents a minimal figure which in all likelihood was much greater, particularly for the lower green to black terrigenous sediments. Quite likely, during the time these terrigenous sediments were accumulating, the depositional site was much closer to the shoreline of India than it is today, perhaps actually being part of the main Indian landmass. In this regard, the clay minerals are dominated by montmorillonite of probable Deccan Trap origin. Alternatively, a significant portion of the Laccadive-Chagos Ridge could have been emergent at this time. If, as believed by most, this ridge is of basaltic composition, it too could have provided a source of montmorillonite. Of the two possibilities, the former is more plausible because the montmorillonite-rich clay assemblage persists into younger Site 219 sediments, sediments deposited after deep subsidence. Further, if the assumption (see Chapter 3) is correct that 1500 meters of additional sediment are present between the bottom of Hole 219A and the basalts below, then most likely much if not all of the northern Laccadive-Chagos Ridge was already mantled by a thick sediment cover. In either event, an apparently continuous shoreline, providing a direct route of faunal migration from this site to the east coast of India, was in existence, because, as was shown in Chapter 3 , an assemblage of shallow benthonic foraminifera in the Pondicherry Formation is identical to that occurring at Site 219. In addition, the synchronous presence of shoreline facies in both places indicates that at least part of the stable Indian Peninsula was at the same elevation as part of the northern Laccadive-Chagos Ridge. That this entire area was still some distance south of the equator during this period is suggested by a scarcity of tropical planktonic forms in the foraminiferal assemblage. This is thought to be indicative of warm-temperate or temperate areas.

A transgression of nearby land areas toward the end of the Paleocene is suggested by the sedimentological data. The terrigenous sediments are gradually replaced by 


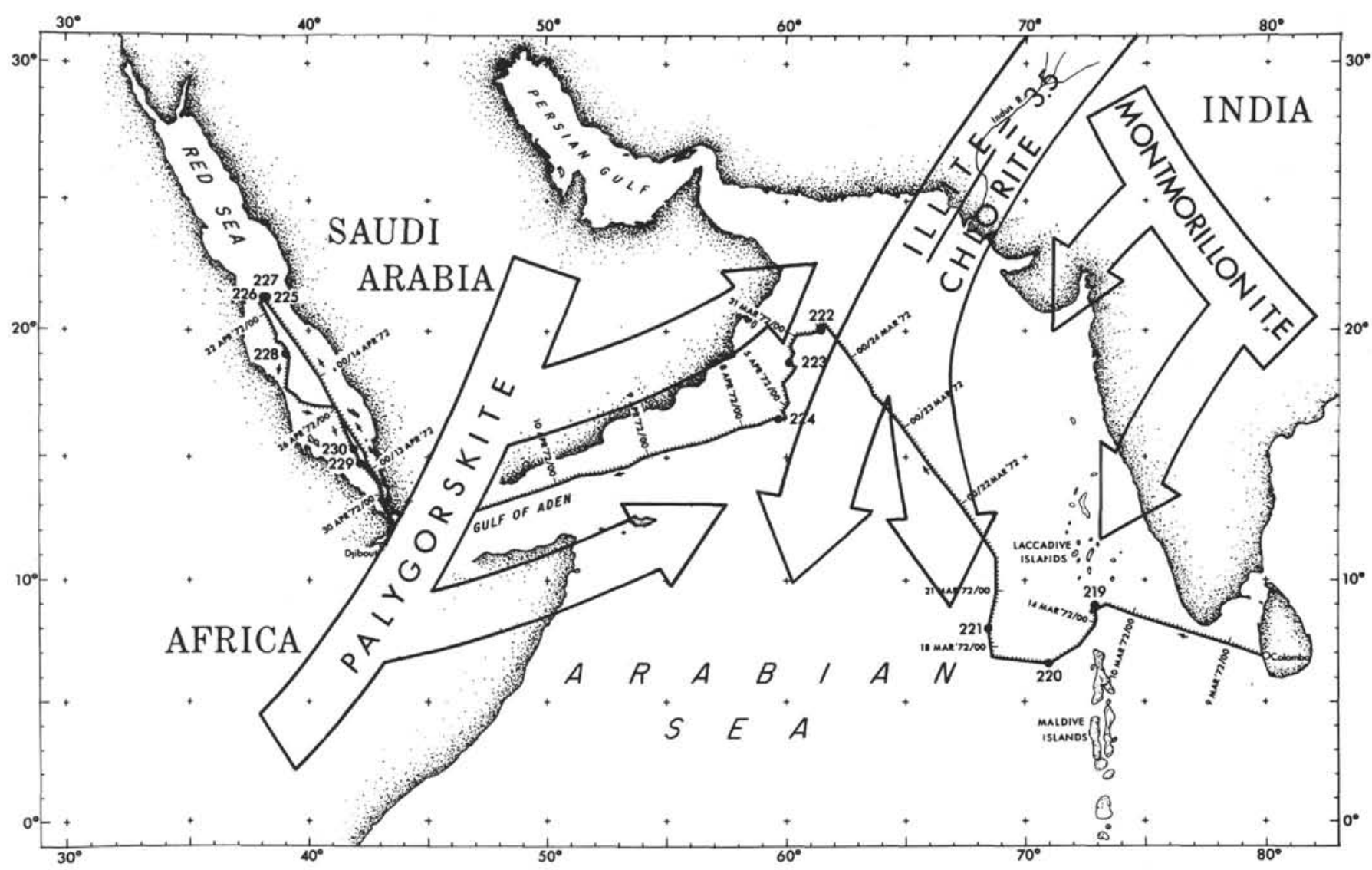

Figure 1. Transport paths of diagnostic minerals in the Arabian Sea.

comminuted thick-walled mollusks, other macrofossils, and benthonic foraminifera. This calcareous mash has a high glauconite content, indicating a decreasing sedimentation rate. Common cross-bedding of this coarse debris attests to a high energy environment. All the above characteristics suggest, not so much a deepening of the depositional site, as a further advance of the sea over adjoining land areas, resulting in a decrease in the supply of terrigenous material. This is corroborated by larger foraminifera, which indicate water depths of only 20 to 40 meters, a depth shallower than that for the underlying strata. Perhaps till then the rate of sediment accumulation at the site exceeded subsidence and the site literally built itself upward into shallower water.

Commencing after Paleocene time there was a significant and abrupt increase in water depth at this site, resulting in several lithologic and paleontologic changes. The Lower Eocene sediments no longer represent a shelf current deposited foram sand facies but become a typical deep-water pelagic foram chalk facies. Locally, the sediments contain phosphatic concretions. The fossils change to deep-water types with planktonic foraminifera now dominant over benthonic varieties. The high concentration of planktonic foraminifera suggests that moderate current activity, limited mostly to winnowing action, prevailed at the site. Paleontologically, an unconformity spanning approximately $5 \mathrm{~m} . \mathrm{y}$. separates these two facies. Succeeding the foraminiferal chalks are the even deeper water aspects of Middle Eocene nannofossil chalks and ooze, which suggest depths of several thousand meters.

An interpretation which can be made here is of rapid subsidence beginning in Eocene time accompanied by a period of sedimentary bypass and/or erosion as the site, perhaps, occupied an upper slope location. The presence of the phosphatic concretions suggests that currents may have kept the site bare of sediment until a diminution in velocity allowed the winnowed foram ooze to accumulate.

From later Early Eocene to the Early Miocene, conditions at Site 219 remained fairly constant, and the main source of sediment was a continual rain of pelagic fossil tests. This was a period of slow, gradual accumulation of biogenous oozes, and chalks. A continuing absence of even the finer grained terrigenous particles gave rise to almost pure white sediments. This suggests that much of peninsular India was submergent at that time. Most of the Eocene sediments have a significant radiolarian admixture which in places has altered to chert. There is also a large amount of micarb, which most likely represents altered nannofossil elements. Of the calcareous fossils, the nannofossils dominate the Eocene and Oligocene sediments. However, there is a gradual increase in foraminifera in the younger sediments to where in the Early Miocene the oozes consist almost entirely of this fossil group. That this is not simply due to a change in the CCD level or increased productivity is documented by the sedimentation rate which shows only a minor increase. More likely, the depositional site experienced current activity over the 
Laccadive-Chagos Ridge. Additional evidence for this is the presence of a small unconformity in the foraminiferal ooze of Core 13. The exposed topographic setting of this site is obvious on Figure 5, Plate 1.

The stratigraphic column on this Plate shows a 19-meter drilled interval between the base of the foram ooze and the underlying nanno dominated oozes. As this interval spans between 11 and 15 m.y., it is very likely that an erosional unconformity occurs there also.

Limited clay mineralogical data exist in this interval. An Upper Eocene sample contains a montomorillonite (i.e., Deccan Trap) dominated suite. The next younger sample taken in Lower Miocene sediments still has sufficient montmorillonite to show the influence of a basaltic source, except that now a high illite/chlorite admixture is present as is a large amount of palygorskite. The proportions of various sedimentary constituents in Lower Miocene sediments reveal that biogenous productivity was still the main contributor of sediments with a minor contribution coming from the erosion of the Indian Peninsula. However, the influence of the Indus River discharge and eolian transport from the western side of the Arabian Sea was now being felt. Although because of a sampling gap this is probably not the oldest Indus or eolian detritus at this site.

The last significant change in depositional regime occurred beginning in Middle Miocene time. The reoccurrence of nannofossils as the dominant biogenous (and overall) constituent of the sediments indicates a waning of current activity at the site. More significantly, the influx of terrigenous clay also became greater at that time. It showed a further increase at the beginning of the Pliocene to where its contribution amounts to from one-third to one-half of the total sediment constituents. The increasing terrigenous contribution was accompanied by an increase in the sedimentation rate. The same sediment sources, i.e., eolian, Indus River, and Deccan Trap, persisted during this period. Their importance changed, however, and it appears that the quantity of Indus River and Deccan Trap material increased relative to that of the eolian source. The relative proportions of the three sources is approximately Indus River $3 / 6$, Deccan Traps $2 / 6$, and eolian $1 / 6$. The increase was not at the expense of palygorskite because the rate of influx per unit time of this mineral remains the same. The clay changes probably reflect increased Indus River discharge plus greater erosion of the Indian Peninsula. These conditions of sedimentation appear to persist to the present day. It thus appears that the present geographic relationship of Site 219 to the surrounding areas became established some time during Middle or Late Miocene time.

In addition to its implications as to conditions at and near the site, the stratigraphic record at Site 219 has some broader implications as well. It is tempting to speculate that the several thousand meters of subsidence which began in Eocene time at Site 219 may have been related to the initial uplift of the Himalayas which Wadia (1968) believes occurred during the Eocene. First though, a closer geochronologic tie must be constructed between these two events to verify whether they were truly synchronous.

Several items of regional significance can be established, however. First, the clay mineral assemblage which characterizes the Indus River discharge, and whose influence is reflected in the younger sediments at this site, did not influence Early Eocene sedimentation of Site 219. Consequently, one must assume that the sediment discharge from a proto-Indus River formed by the birth of the Himalayas was much less at that time and/or the dominant clockwise circulation pattern of the wind-driven circulation in the Arabian Sea had not yet been established. The reason for the absence of such a circulation pattern could be that the present configuration of land and sea areas in the northwestern Arabian Sea had not yet been established. Such rank speculations could be clarified by a closer look at the clay mineralogy of Cenozoic marine formations which occur in the subsurface along the western Indian coast. A second item of interest is establishing that at least a portion of the Laccadive-Chagos Ridge and of the Indian Peninsula (whose tectonic stability causes the entire feature to respond to stress as one structural unit) were at the same approximate elevation during Paleocene time. Today there is about 2,000 meters of difference in their elevations. The inference is obvious. The northern Laccadive-Chagos Ridge is not an integral part of India, as believed by some, but a separate structural element.

\section{Site 220}

Site 220 is situated on a broad irregular platform which lies west of the nearby Laccadive-Chagos Ridge and east of the deeper Arabian Abyssal Plain. Its stratigraphic history, as recorded in a 350-meter penetration, is largely tied to that of typical oceanic rise generated crust which, because of lithospheric cooling, sinks from deep water into ever greater depths as it travels away from the ridge crest. It, therefore, has a different structural history than Site 219. Nevertheless, as subsequent discussions will show, the timing and influence of several depositional agents at Site 219 can be tied to those at Site 220 .

The igneous strata at the bottom of the hole represents typical oceanic basalt. They contain two thin layers of altered nannofossil chalk. The 329 meters' of sediment above the basalt spans 51 m.y., from Pleistocene through Early Eocene time. As such, deposition began soon after an Eocene transgression covered the sole potential nearby source of terrigenous debris, i.e., the Indian Peninsula. As a consequence, biogenous planktonic microfossils were the main sediment constituent available to Site 220. Their constant rain of slowly settling particles continued until the end of Oligocene time. In this manner the lower of two distinctive stratigraphic intervals developed at this site. This process was seemingly at a maximum during the Early and Middle Eocene when pelagic oozes were deposited at rates of $<70 \mathrm{~m} / \mathrm{m} . y$. and $19 \mathrm{~m} / \mathrm{m} . y$., respectively. The tests of both siliceous and calcareous microfossils are present in this interval. Radiolaria and sponge spicules comprise as much as 30 percent of the sediment constituents with nannofossils making up most of the remaining materials. Much of the Lower Eocene exhibits diagenesis of siliceous fossils which formed chert beds and the alteration of nannofossils into a high proportion of micarb particles. The chert buildup, which also occurred at Sites 219 and 221 in approximately the same stratigraphic interval, appears to be part of a regional Eocene chert development. It represents 
one of the more obvious acoustostratigraphic horizons traceable in the Arabian Sea.

Within the oldest oozes, a well-preserved planktonic foraminiferal assemblage attests to the relatively shallow aspect of the deep-water fossils as they accumulated at the crest of a spreading ridge. The one clay mineral analysis, which is from Lower Eocene strata, indicates that quantitatively clay barely qualifies as a trace constituent. The clay mineral assemblage is dominated by montmorillonite, ${ }^{2}$ which suggests a Deccan Trap source.

Several slight changes in depositional environment, with resultant changes in sediment composition, encompasses Late Eocene to Late Oligocene time. Sediments deposited in the lower portion of the stratigraphic interval consist almost entirely of white nannofossil ooze and chalk. However, the effects of ever increasing water depths is shown by the more corroded aspect of foraminiferal assemblages and by a reduction in depositional rates to between 6 -and $12 \mathrm{~m} / \mathrm{m} . \mathrm{y}$. As in other seas, the abundance of siliceous tests dropped off considerably from earlier Eocene occurrences. Again, pelagic biogenous ooze production was almost the sole source of sediment constituents, and, as at Site 219, the nearly complete absence of terrigenous contamination is shown by the white color of these oozes. An upper Upper Oligocene sample, analyzed for its clay content, contains an assemblage showing that the Indus River was now the dominant clay source and that the Arabian Sea eolian source to the west and a Deccan Trap source to the east played less important roles. It is of significance that this analysis extends the initial occurrence of Indus River detritus back to approximately $25 \mathrm{~m} . \mathrm{y}$. (compare with 18 million years at Site 219). An absence of analyses from immediately older rocks indicates that this is still a minimal figure.

The only major change in the depositional regime occurred somewhere between Late Miocene and Late Oligocene time, the effects of which persist to the present. This change developed the last of the two major stratigraphic intervals found at this site. Basically, it involved changing from pelagic draping of biogenous ooze over abyssal hill structure to a combining of this process with that of gravity sedimentation. ${ }^{3}$ The gravity sediments represent the extreme edge deposits of a locally ponded

\footnotetext{
${ }^{2}$ Normally, the presence of montmorillonite in pelagic sediments indicates derivation from weathering of basalts or volcanic glass in an oceanic area. The Carlsberg Ridge could be thought of as one such possible source. However, here in the southern Arabian Sea the not too distant Deccan Traps on the Indian Peninsula provides a more prominent source for this mineral. This was shown by Goldberg and Griffin (1970) for present-day sediments and is indicated by conclusions derived at Site 219 for ancient sediments. The author acknowledges that in subsequent discussions pertaining to Sites 220 and 221, where a Deccan Trap source is indicated, a minor portion of the montmorillonite minerals could have had another source.

${ }^{3}$ In this text the term gravity sediment is employed for those strata whose distribution is controlled mainly by inertial and gravity flow. Their habit is to fill topographic lows with flat-lying deposits. They encompass mostly turbidity currents with some associated slide and slump deposits plus turbid layer accumulations.
}

abyssal plain. The relationship of this plain to the draped sediments can be seen on the seismic record (Figure 6, Plate 1).

The sediments in this interval consist of a mixture of nannofossils and brown detrital clay and of turbidite sands made up largely of foraminifera. The foraminifera in the sands are dominantly well-preserved benthic forms which contrast with the impoverished and partially dissolved state of mostly planktonic forms in the nonturbidites. The turbidites also contain minor amounts of Eocene fossils. Along with the increase in detrital material is an increase in organic carbon.

The turbidite sands constitute but a small part of the total section, and although more were present than indicated on the core forms for Site 220, they, by themselves, may not be the only gravity sediments at this site. It is possible that some of the finer grained sediments may represent turbid layer deposition although most of them probably represent a grain-by-grain accumulation. The most likely source of the gravity sediments is the Laccadive-Chagos Ridge. An Indus River source via the Indus Cone can be ruled out because this site is above the level of the adjoining Arabian Abyssal Plain. In either event, compositionally, the fine-grained sediments are a brown nanno clay which corresponds to those found nearby at a similar depth in a piston core by Stackelberg (1972). He noted that the fine-grained particles there averaged about 50 percent carbonate. The carbonate content of sediments in this interval at Site 220, which varies from 34 to 67 percent, also averages 50 percent.

Quite revealing is a compositional comparison of this nanno brown clay interval with the uppermost terrigenous interval at Site 219. An examination of their carbonate content generally shows somewhat lower values at Site 220, an aspect to be expected because of the greater water depth there. Of greater significance, however, is a comparison of their clay mineral assemblage which shows identical constituents present in similar proportions. Therefore, one can conclude that, as at Site 219 , southerly transport of Indus River sediments, transported through the water column, provided the source for one-half the clay minerals, eroded Deccan Traps one-third, and eolian transport the remainder. This compositional similarity of the fine-grained components is compatible with either 2 nd cycle turbid layer transport or pelagic grain-by-grain accumulation of the clay material.

Further confirmation of the close affinities of the clay minerals in these upper intervals at the two sites is provided by comparing their rate of accumulation. Although the sedimentation rate at Site 219 is twice that of Site 220, by compensating for the greater amount of calcareous constituents at the former site, the amount of terrigenous detritus is only 20 percent greater at Site 219 . This figure is quite compatible with the farther offshore location of Site 220.

The only obvious difference between these sediments at the two sites (besides a moderate difference in carbonate content) is their color. Those at Site 219 have the gray and green colors typical of reducing conditions in terrigenous deposits, whereas at Site 220 , they have the hues and appearance of typical "brown" highly oxidized pelagic 
clays. Germane to this observation are Stackelberg's findings (1972) in the same general area, namely, that the presence or absence of oxidized sediments and their thickness was generally a function of water depth. He found that reducing conditions prevail through an entire sediment core in depths down to 1500 meters. The first appearance of thin oxidized layers begins below this depth. Their thickness shows a gradual increase until at about 3500 meters reducing conditions are gone entirely.

As pointed out earlier, much of the shallow and intermediate depth water in the Arabian Sea has a low oxygen content. When relating this content to the initial development of brown clay, it appears that oxidizing colors begin where $\mathrm{O}_{2}$ values rise above 0.5 to $1.0 \mathrm{ml} / 1$. These values correspond to water depths ranging from 1500 to 2000 meters (Wyrtki, 1971). Therefore, the difference in water depth between Sites $219(1764 \mathrm{~m})$ and $220(4036 \mathrm{~m})$ largely explains the sediment color differences between the two sites.

Establishing when the underlying nearly pure white biogenic nanno oozes at Site 220 changed to the brown nanno clay facies is difficult to determine as it lies within a 48-meter coring gap. However, an understanding of why the change occurred would help to pinpoint when it occurred and provide a basis for extrapolating the lithology of the coring gap.

No doubt, because of the close relationship of the uppermost sediment intervals at Sites 219 and 220, one can postulate a more rapid clay influx beginning in Middle Miocene time as a factor in the lithology change. Increasing clay deposition, though, is not the sole reason. An examination of the foraminiferal assemblages in the white and the brown sediments reveals more intense solution effects in the latter. Relevant to this finding is the observation (by considering carbonate contents and sedimentation rates) that the rate of nannofossil accumulation in the brown sediments was one-fourth that of the white strata. This is a further indication that increasing carbonate solution was a factor in the higher clay content.

The more intense solution obviously means that the site dropped closer to the CCD. Did it actually drop below this depth in the coring gap, and if so, when? In this respect, the color photos of Core 5, which is at the top of the coring gap, exhibit a more intense brown color toward the bottom of the core, indicating a decreasing carbonate content. Another point, the 48-meter coring gap between the Oligocene white nanno ooze and the Miocene brown nanno clay spans about 16 m.y. of time. With continuous deposition, a sedimentation rate of $3 \mathrm{~m} / \mathrm{m} . \mathrm{y}$. is obtained, a rate much lower than any encountered at this site. However, this is not an unreasonable rate for this interval because the comparable time span at nearby Site 221 is represented by brown clays which accumulated at a rate of $2 \mathrm{~m} / \mathrm{m} . \mathrm{y}$. Those brown clays, which reflect deposition below the $\mathrm{CCD}$, began accumulating in Late Oligocene time. Because both sites have a similar setting, except that Site 220 is 600 meters shallower, it is not unreasonable to expect that a similar lithologic sequence developed at the latter site. The only difference would be that because of its shallower setting, it must have dropped below the CCD at a slightly later time. With this interpretation, one would project a brown clay facies beginning somewhere in earliest Miocene time into the coring gap. This facies would gradually change, perhaps in Late Miocene time, to that of Core 5. The lithologic sequence resulting from this interpretation is shown in Figure 2. There it is contrasted with one based simply on extrapolating the lithology of Core 5 halfway down and that of Core 6 halfway up into the coring interval ${ }^{4}$. For comparison, the sediment sequence encompassing the same time span at Site 221 is also shown.

The above interpretive lithologic sequence, which calls on a change from Oligocene white nanno ooze to Lower and Middle Miocene brown clay to Late Miocene and younger brown nanno-rich to nanno clay, necessitates a Neogene rise in the CCD. That this is more than just speculation will be demonstrated in the lithologic analysis of Site 221.

\section{Site 221}

Site 221 has a setting in time and space quite similar to that of Site 220. Its history is also tied to that of oceanic crust generated by a spreading ridge crest, and the difference in water depth between the two sites is only about 600 meters. Yet, there are important differences in the sedimentary processes which prevailed at the two sites.

The tholeiitic basalts, here as at the previous site, contain a sediment layer buried between flows. It was too badly altered for dating purposes. The period of continuous sedimentation began 46 m.y. ago, in the Middle Eocene. As such, it started at the very end of the period of siliceous ooze deposition at Site 220. Consequently, siliceous sediments are represented by only a thin chert stringer at the base of the 261-meter-thick sedimentary section.

Compositionally, the lowest sediment interval, which spans much of Paleogene time, is represented almost entirely by a pelagic nannofossil ooze. This indicates that depositional processes for this period were similar to those at Site 220. There are a greater number of altered nannofossil elements at Site 221, which give rise to more micarb particles. X-ray mineralogy samples taken from Middle Eocene and lower Lower Oligocene cores are dominated by montmorillonite. Its presence in the latter sample serves to extend the youngest time constraint regarding when the Deccan Traps prevailed as the dominant source for clay detritus in the eastern Arabian Sea. The X-ray mineralogy data also sets constraints on the earliest time when an Indus River clay mineral assemblage affected the southern Arabian Sea. By its absence from a lower Upper Oligocene sample at this site and its presence in an upper Upper Oligocene sample at Site 220, its initial appearance is restricted to the period between 25 and 30 m.y.

\footnotetext{
${ }^{4}$ The hole summary form in Chapter 4 and the Site 220 stratigraphic column on Plate 1 , in pocket, utilizes this interpretation because it is less speculative.
} 


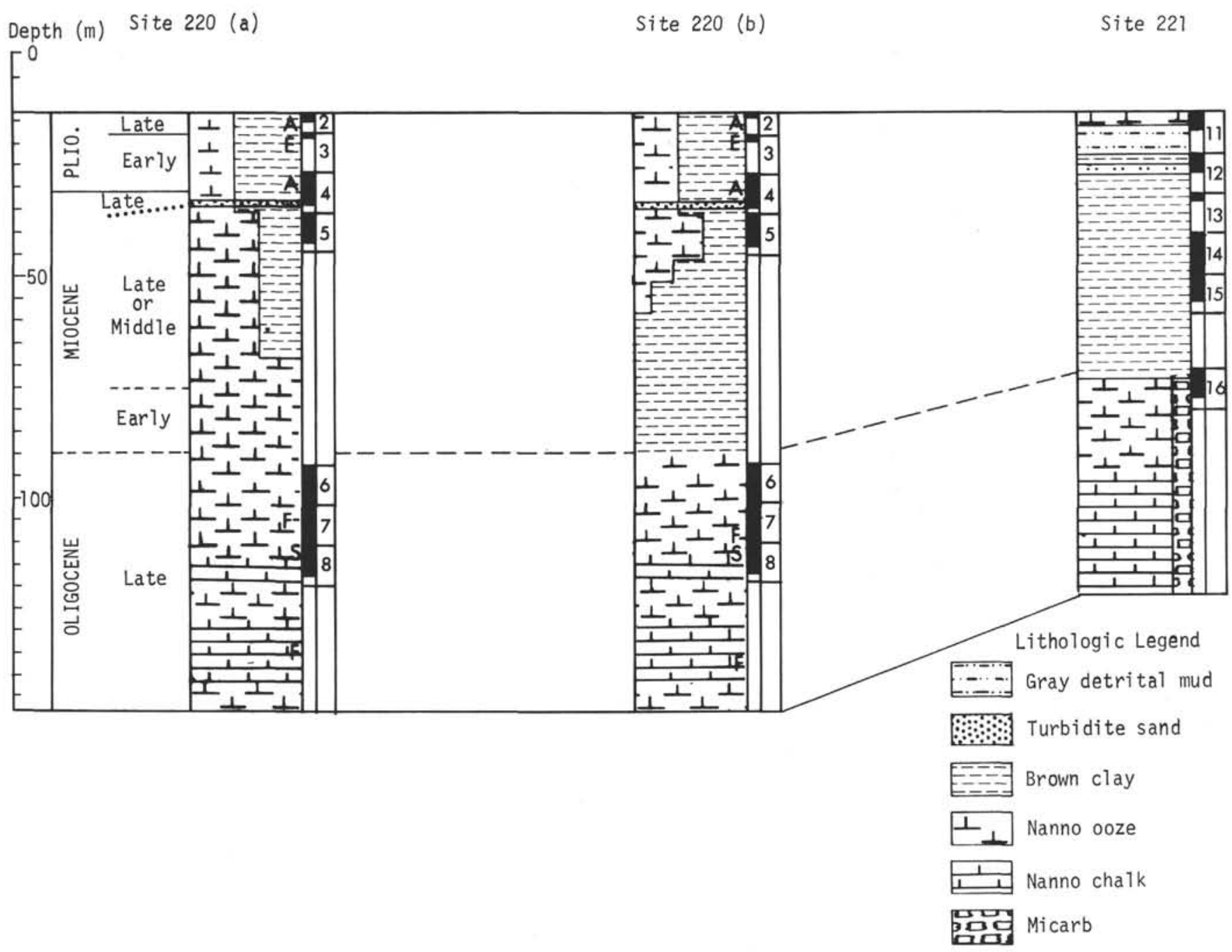

Figure 2. Alternate interpretations of the Site 220 Coring Gap. Column 220(a) based on extrapolating lithologies of Cores 5 and 6, halfway into coring gap. Column 220(b) based on evidence of a change in CCD at Site 221. Column 221 provided as comparison with Site 220.

A departure from anticipated depositional behavior, based on the spreading ridge crest hypothesis, is the abnormally low sedimentation rate of 3 to $5 \mathrm{~m} / \mathrm{m}$.y. for the older sediments at this site. This rate is usually not attained until a site has moved a considerable distance down the ridge flank. The rare occurrence and poor preservation of foraminiferal faunas throughout this interval, including the basal portion, is suggestive of water depths greater than those normally found at spreading ridge crests. If winnowing action by bottom currents was responsible for the low sedimentation rate, an enrichment rather than depletion of foraminifera would be expected. Discussions in Chapter 5 indicate various alternate possibilities, including later volcanic flows burying older sediments. This is a distinct possibility because the seismic record indicates the development of a low broad rise in the basement rocks (see Figure 1, Plate 1 in pocket). At present, the problem remains unresolved.

A significant change in depositional environment followed the period of ooze deposition. Above the biogenous oozes is a rapid transition into a ca. 43-meter-thick brown clay interval almost completely lacking in carbonates. Only a trace of nannofossils is present. Tentative fossil datings indicate that this unit spans about $25 \mathrm{~m} . \mathrm{y}$. Assuming no unconformities are present, a sedimentation rate of slightly less than $2 \mathrm{~m} / \mathrm{m} . \mathrm{y}$. is derived; a rate which typifies many pelagic brown clays.

The reason for the change in environmental conditions at this time is not clear. Lithospheric cooling resulting in greater depth of water must certainly have been a contributing element. However, it is also a possibility that a decrease in biogenous productivity, entrance of more corrosive bottom waters into the Arabian Sea, or a change in seawater chemistry, caused a rise in the CCD. Any of these conditions singly or in combination may have occurred.

The clay composition of a sample taken from the middle of this interval is an indication of the sediment sources active in the Arabian Sea about 15 m.y. ago (an age derived by paleontological interpolation). Montmorillonite, which typifies pelagic brown clays in many oceans, is only a minor constituent. On the basis of the illite/chlorite ratio and the amount of quartz and palygorskite, the Indus River appears to have been the major contributor, followed in importance 
by a western Arabian Sea eolian source. The indication that the Indus River was active here at this time could almost have been anticipated considering the time its products appeared at Site 220.

Verification of Indus River activity during brown clay deposition is also provided by the presence of a thin detrital sand bed just above the clay sample. At first this was taken to be due to downhole drilling contamination from overlying sands, but it now appears more reasonable to interpret it as being an initial distal turbidite bed.

The next dramatic change in the depositional environment took place in the Late Pliocene. By now pelagic sedimentation no longer dominated as the first full effects of distal Indus Cone deposition were being felt in this area. The change was gradual over a 16-meter interval where pelagic and terrigenous sediments are intermixed. Above this is a 111-meter gray Pleistocene terrigenous interval which in the Late Pleistocene accumulated at a rate of $170 \mathrm{~m} / \mathrm{m} . \mathrm{y}$. This represents an 85 -fold increase over that of the brown pelagic clay. The sediments in this interval are well-stratified as can be seen on the seismic record (see Figure 1, Plate 1). Determining which portion of this interval represents the product of turbidite flow and which portion represents the background accumulation of pelagic sediments between flows was difficult to assess. The interval consists of essentially two interbedded facies present in almost equal amounts (see Site 221 stratigraphic column on Plate 1). The one portion is made up of gray coarse and fine-grained sediments, many of which are graded. Compositionally, the sands are mica dominated and the clays have a preponderance of illite over chlorite, little montmorillonite, and substantial quartz and calcite. These characteristics typify the Indus Cone sediments at Site 222. The other portion is the same color, also contains graded beds but is compositionally entirely different. Both the coarse and fine material is preponderantly of carbonate, most of which is aragonitic. The aragonite is in the form of fecal pellets and needles, certainly an anomalous accumulation at the 4650-meter water depths prevailing at this site. The clay minerals again have the same compositional attributes as those previously mentioned but now in addition contain one-fourth to one-half montmorillonite. In this regard they are quite similar to the Plio-Pleistocene clays at Sites 219 and 220.

If the calcareous sediments represented pelagic deposition, then their total thickness should have been slightly less than their 12-meter-thick Pleistocene representation at Site 220. However, at Site 221 they are approximately 60 meters thick. Furthermore, at the water depth prevailing at this site, their carbonate content should only approximate the 30 percent found by Stackelberg (1972) for nearby nonabyssal plain sediments at a comparable depth, and not the 65 percent which actually occurs. The more obvious conclusion is that these are also turbidite deposits but are derived from a different source. Pertinent to this interpretation, Stackelberg also found extensive accumulations of aragonitic pellets and needles on the shelf as well as in turbidites on the lower continental rise off western India.

The above data strongly suggest that coarse aragonitic detritus periodically slumps off the outer shelf of India into the Arabian Sea. During its descent, it would incorporate slope muds originally derived from the suspended debris of the Indus River and from the erosion of basaltic terrain of western India. A further consequence of this interpretation is that nearly half of the eastern Arabian Abyssal Plain sediments were not derived from the Indus Cone.

The mica-rich sands, which typify an Indus Cone source, occur throughout the Plio-Pleistocene turbidites at Site 221. This indicates that the eastern side of the Indus Cone and Arabian Abyssal Plain were actively being built by this source throughout this time.

Sediments at this site, in addition to providing information relative to the history of the Indus Cone, also, when combined with other data, define a change in the CCD level in the Arabian Sea. At this site, the progression of change in fossil types and their preservation in going from Eocene to Oligocene biogenous oozes, reflect increasing carbonate solution with decreasing age. Additional solution is indicated by the complete absence of carbonate in the overlying brown clays. Lithospheric cooling with an attendant increase in water depth can easily account for these changes. To decipher whether a changing CCD was also a factor would require a more detailed examination of the fossils.

However, there is evidence at this site that a drop in the CCD occurred near the end of brown clay deposition. The sediments at the top of this interval contain a trace of nannofossils. Their amount increases to from 11 to 15 percent in the immediately overlying gray clays. Of course some of this carbonate may be redeposited, and the higher sedimentation rate of these sediments may have inhibited the dissolution of carbonate. Further data from younger sediments is meaningless because they also are almost entirely redeposited. Much better evidence is provided by Stackelberg's findings above of 30 percent carbonate in pelagic sediments. These sediments are of Late Quaternary age (Zobel, 1973). This bit of evidence clearly demonstrates a rising CCD level since the carbonate barren brown clays were deposited.

\section{Northwestern Area}

Again, as in the southern Arabian Sea, only two of the three sites contribute measurably to the stratigraphic history of the region. Site 222 gives useful data down to Late Miocene time, and Site 223 provides information through Late Paleocene time. The large drilling gaps between cores at Site 224 make it possible to resolve only broad aspects of its depositional history.

\section{Site 222}

The 1300-meter penetration of Site 222 provides the deepest hole drilled to date by DSDP; yet, because of high sedimentation rates, total stratigraphic penetration represents only $6 \mathrm{~m} . \mathrm{y}$. It encompasses only latest Pleistocene through late Late Miocene time.

Because this site is located on the Indus Cone, it comes as no surprise that Indus River detritus dominates the stratigraphic column throughout this period. This column can be divided into only two stratigraphic divisions. They are based on variations in the amount of this detritus which 
in turn reflects on the importance of various contributory depositional processes.

The lowest interval, encompassing Pliocene through late Late Miocene time, spans approximately 1220 meters or almost 95 percent of the geologic column. Deposition during this period was extremely rapid, ranging from 135 to $>600 \mathrm{~m} / \mathrm{m}$.y. Sediments consist mostly of massive muds interspersed with about ten percent of thin sand beds.

The subordinate role of sand in the make-up of the stratigraphic column at a site situated on a submarine sediment cone was somewhat surprising. As regards the total contribution of the turbidite mechanism to sedimentation there, this was difficult to judge. Many of the sand beds, which are fairly thin, grade upward into thick massive silty clays which lack characteristic turbidite structures. Also, a few of the sands give sedimentological evidence for a nonturbidite origin (see Chapter 10). It is possible that many of the finer clastics represent accumulation through turbid layer transport or by contour currents. The latter mechanism could also be invoked for some of the sand beds. Turbid layer deposition as a transport mechanism at this site is somewhat questionable because of the presence of reworked foraminifera throughout most of the sediments. As Moore (1966) has shown, flow velocities competent to transport particles that size are normally not present in this type of flow. Compositionally, the muds and the clay fraction of the sands are dominated by illite and chlorite with an illite to chlorite ratio of 3 or 4 to 1 . Most of the remaining constituents are quartz, calcite, and lesser quantities of montmorillonite. As shown previously, this assemblage typifies the Indus River discharge.

Although all the sand beds and most of the muds are gray, some of the latter are green. The green layers appear to distinguish periods when a change in depositional processes occurred at this site. These muds are lacking in sand beds, have a much higher nannofossil content, and are usually strongly bioturbated, an aspect completely lacking in the gray muds. Their assemblage of clay minerals, however, is similar to that of the gray muds, indicating that the Indus River was still the dominant source. The green layers, which are only $5 \mathrm{~cm}$ to 6 meters thick, are interspersed throughout the section. They have an average periodicity of about 40,000 years (based on an extrapolated frequency of 100 layers within a 4 m.y. time interval). Table 3, Chapter 10 (in pocket) indicates the stratigraphic position of the gray and green layers and highlights some of their characteristics.

The sedimentological evidence strongly indicates that the green layers represent periods of appreciably slower deposition than that of the gray layers. Thus, the high sedimentation rates, which encompass the entire interval, are actually averages which must represent fluctuations between high and even higher rates. Unfortunately, paleontological zonations are not sufficiently refined to document the time span of individual green layers. Their development would seem to be tied to a change in the rate at which Indus River material reached this site. Variations in total suspended load of the Indus drainage due to major climatic changes does not appear to be a valid reason because of the great frequency with which they would have had to occur. More likely, perhaps, are variations either in the activity of the dominant submarine channel supplying sediments to this site or of general channel activity on the western side of the Indus Cone. A decrease in either would allow nongravity agents to become more important contributors.

The uppermost interval, which is only 80 meters thick, apparently represents all 1.8 m.y. of Pleistocene time. Consisting entirely of green mud, it has the same characteristics as the green layers encountered deeper in the hole, except for the absence of bioturbation structures and for a clay mineral assemblage which contains a significant admixture of palygorskite. The sedimentation rate for this green interval is much less than that of the older strata. That this decreased rate was due to a diminution of submarine fan activity rather than to a change in climate can be shown on the seismic profiler record (see Figure 7, Plate 1). There, at $1145 \mathrm{hrs}$. and 1315 hrs., the drill site is seen to be elevated above the general level of the fan surface due to fault movement and thus was out of reach of turbidite or turbid layer transport (also note adjoining depressed area representing the Owen Graben). Giving added evidence for a diminution in the rate of sediment influx is the presence of palygorskite. As demonstrated earlier, this mineral, which appears to reflect eolian input, could be expected to become more prominent as the influx rate of other constituents decrease. Within this interval, an average palygorskite content of 10 percent provides a minimal measure of the eolian contribution to the sediments. Another important admixture was provided by pelagic planktonic production. This production resulted in an average nannofossil content of 50 percent. Combined, these two depositional processes account for about two-thirds of the total sediments. Nongravity type sedimentation of fine-grained Indus clastics must account for the remainder. Adjusting the influx rate for the two aforementioned constituents, the rate of Indus Cone input to the upper interval was only one-twentieth that of the $300 \mathrm{~m} / \mathrm{m} . \mathrm{y}$. average rate for the lower interval.

Lack of Pleistocene Indus Cone activity appears to have been more widespread than just at Site 222. To the southwest of this site, another crossing of the Owen Graben, where this feature has an even more prominent development, shows it to be completely lacking in the fill of any stratified sediments. Its topographic expression can be seen on Figure 8, Plate 1. Similar unfilled grabens appear all along this fracture zone extending as far south as its intersection with the Carlsberg Ridge. It appears that the flow of gravity sediments along the west side of the Indus Cone and Arabian Abyssal Plain has been inconsequential since, perhaps, the beginning of Pleistocene time. This conclusion is reinforced by the presence of the Pleistocene Indus Cone sands at Site 221, a location more than twice as far from the Indus Submarine Canyon as Site 222.

The temporal span of the strata penetrated at Site 222 encompasses only $6 \mathrm{~m} . \mathrm{y}$. of geologic time. During this period, sedimentation was dominated by the Indus Cone. The answer as to when this cone first influenced sedimentation there, and what, if any, sediments underlie its deposits, remains buried beneath a thick wedge of sediments. However, by making a few basic assumptions it 
is possible to speculate on the age, thickness, and character of the geologic record not yet penetrated.

An extrapolation of the sea floor spreading ages and rates recognized by McKenzie and Sclater (1971) suggests a crustal age of approximately 70 m.y. at the base of the sediment column. Subtracting the 6 m.y. already encountered, this leaves 64 m.y. of geologic time as yet unaccounted for. The amount of sediment deposited during this time span can be derived from the geophysical studies of Neprochnov (1961). He contoured a total sediment thickness of $2.5 \mathrm{~km}$ in the vicinity of Site 222 . This depth when added to the $3.5 \mathrm{~km}$ water depth at Site 222 exceeds the depth to Layer 2 predicted on the basis of the crustal age versus depth curve of Berger (1972) by $0.5 \mathrm{~km}$. However, by taking the isostatic effect of the sediment load into account, this difference can be reconciled. Consequently, the 64 m.y. of unaccounted for geologic time must be distributed over about $1.2 \mathrm{~km}$ of sediment (i.e., $2.5 \mathrm{~km}$ total thickness minus $1.3 \mathrm{~km}$ penetrated at this site).

To determine the type of sediments present in that interval, several clues can be obtained from an examination of (1) the normal sequence of pelagic sediments deposited on oceanic crust, and (2) other Leg 23 Arabian Sea drill sites.

In Atlantic Ocean areas away from the influence of terrigenous sources, normal pelagic sedimentation at a ridge crest begins with the deposition of biogenous ooze at rates of 15 to $20 \mathrm{~m} / \mathrm{m} . \mathrm{y}$. This is followed by steadily decreasing rates of ooze accumulation which in turn gradually develops into a brown clay facies as the depositional site moves conveyor-belt fashion into deeper water. By then, sedimentation rates will have decreased to 2 or $3 \mathrm{~m} / \mathrm{m}$.y. The development of the brown clay usually requires several tens of millions of years, at which time an original ridge crest water depth of about 2700 meters (see Berger 1972) may have dropped to between 4500 and 5100 meters. The brown-clay facies will then tend to persist during the remaining history of a site unless a change in the level of the CCD occurs or if plate motion transports it to within range of terrigenous influences. Sites 220 and 221, except for a slight deviation, both developed the above pattern of a normal pelagic sequence evolving into a brown clay facies. (This deviation is the anomalously low rate of biogenous ooze deposition at Site 221 during its period of ridge-crest sedimentation.) At both sites, the change into the brown clay facies required 25 to 30 m.y. Perpetuation of this facies was destroyed by a strong terrigenous influx from the Indus Cone at Site 221 and by an apparent change in the CCD level together with some turbidite activity at Site 220 .

Plate reconstructions for the period 51 m.y. (the oldest strata found at Sites 220 and 221) to 70 m.y. suggest that the proto-Arabian Basin would not have been influenced by terrigenous sources during that time span. Consequently, it is reasonable to assume that normal pelagic sedimentation would have occurred at Site 222 during this period.

Utilizing the above data, one can reconstruct the 70 m.y. old $2.5-\mathrm{km}$-thick sediment section at this site as follows: From the period 70 to about 45 m.y. approximately 250 meters of biogenous oozes accumulated. Although consisting mostly of nannofossils, they probably developed a significant admixture of siliceous fossils during their initial phase of ridge crest deposition and again later during the Early and Middle Eocene interval of opaline fossil generation in the Arabian Sea. In the period 45 to 25 m.y., deposition below the CCD probably occurred, resulting in the accumulation of approximately 50 meters of brown clay. In this manner, the first $45 \mathrm{~m} . \mathrm{y}$. of time at this site are represented by about 300 meters of pelagic sediments.

Afterwards, the initial effects of Indus Cone sedimentation would have begun to be felt at this site and the brown clay facies would have been succeeded by the gray clays of distal terrigenous muds mixed, perhaps, with some pelagic sediments. It has already been shown that during the final 6 m.y. of time at this site, 1300 meters of mostly Indus Cone sediments accumulated. It was also calculated that their sedimentation rate had reached a peak of $>600 \mathrm{~m} / \mathrm{m} . \mathrm{y}$. for the period spanning from 5 to $6 \mathrm{~m} . \mathrm{y}$. Such a high rate of accumulation obviously could not have persisted during the period 6 to 25 m.y. because by simple mathematics only about 900 meters of section remain unaccounted for. As in most basins affected by turbidity currents, one can assume a gradual encroachment of terrigenous sediments so that extremely high sedimentation rates probably did not begin at this site until some time in the Late Miocene. The total sediment sequence envisioned for Site 222 is shown on Figure 3.

\section{Site 223}

This site essentially occupied three or more differing topographic settings within a 57 million year span of recorded geologic history. During that period, it was also subjected to a variety of depositional processes each continually changing in its importance. Recognizing all the environmental factors and when they affected this site is difficult to decipher. Nevertheless, some of the more important events within the 740 meter stratigraphic section could be determined and are described below.

Compositionally, the basaltic rocks encountered at the bottom of this hole are not the normal subalkaline type generated at mid-ocean ridges. Consequently, the average water depth of 2700 meters usually encountered at a spreading ridge crest probably did not exist there when sedimentation began. Evidence from the geologic column on the initial sedimentation depth is contradictory. Based on vesicle size in the basalts, an extrusion depth of $<800$ meters is indicated. However, on the basis of scarcity and state of preservation of nannofossils and foraminifera in the oldest sediments, a water depth greater than the CCD level must have prevailed. This contradiction could be explained by assuming that the igneous activity at this site resulted in the formation of a topographic prominence which later subsided. Such a prominence would induce current turbulence (during its subsidence history), resulting in nondeposition until the topographic relief was eliminated by the surrounding sediment buildup. Thus, while it is not clear what the topographic setting was when volcanism ceased, it seems evident that deep-water conditions prevailed when sedimentation began.

The oldest stratigraphic interval, which encompasses Late Paleocene to Early Eocene time, is a typical brown pelagic clay consisting mostly of montmorillonite, zeolites, and cristobalite together with lesser amounts of palygorskite. 

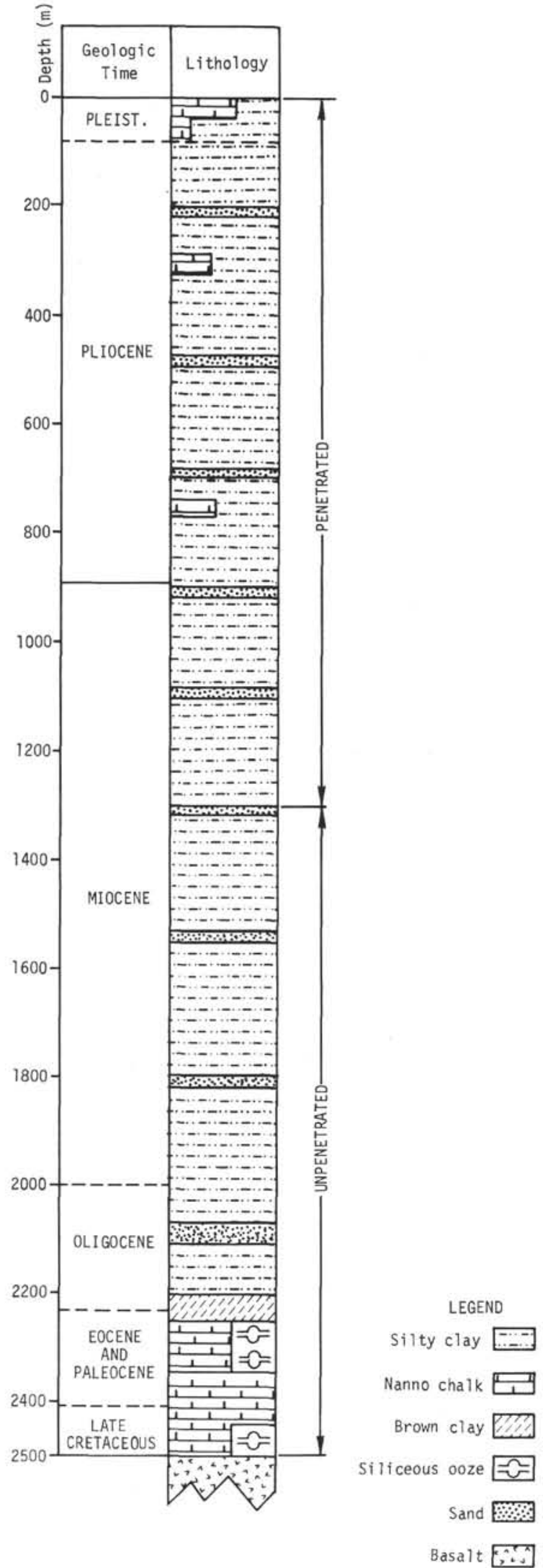

Figure 3. Site 222. Showing in a generalized manner the 1300 meters of the strata penetrated at this site and the extrapolated thickness and lithology of the unpenetrated stratigraphic section.
In addition, badly corroded radiolarians appear in the Eocene portion of the interval. These sediments accumulated at a rate of between 13 to $20 \mathrm{~m} / \mathrm{m} . y$., a figure surprisingly high for pelagic clays. Several inferences can be derived from these sediment characteristics. First, the presence of some Eocene siliceous fossils indicates high biogenic productivity in surface waters. That this productivity is so poorly represented in the sediments confirms the presence of a great depth of water. Secondly, the relatively rapid accumulation of montmorillonite throughout this interval suggests that a nearby active volcanic area was the source rather than the more distant Deccan Traps of the Indian Peninsula.

The origin of the palygorskite in this interval is not clear. As previously shown, it makes its first appearance as an eolian constituent (derived from west of the Arabian Sea) at Sites 219 to 221 in Late Oligocene time. Its earlier appearance at this site could be due either to differing paths of tropospheric transport at that time, or to in situ formation in the sediments. Its association with the minerals mentioned above, and its presence in rather large amounts, suggest an authigenic origin is more likely.

During this early phase of its sedimentary history, Site 223 had not experienced the effects of structural uplift which were to occur later along the Owen Fracture Zone. It therefore quite likely had a topographic setting akin to that of the Arabian Basin to the east and indeed, topographically, probably was part of this basin. However, some time later it became involved in the prominent structural movement along the fracture zone. This movement was in the manner of a hinge-like uplift along its west side which resulted in the formation of the prominent Owen Ridge, whose conspicuous east-facing scarp can be seen on Figure 4, Plate 1. The formation of this ridge profoundly influenced sedimentation in its vicinity. Consequently, its effects are reflected in the stratigraphic column at Site 223. Being a considerable distance down the ridge flank, the actual raising of the sea floor at this site may not have been too great. The change in elevation would be dependent on how far the site was from the fulcrum of hinge movement; conceivably, it was quite close.

On the basis of stratigraphic and geophysical data, the period when structural movement leading to ridge development had ended occurred no later than Early Miocene time and possibly somewhat earlier. The stratigraphic evidence consists of a prominent unconformity and of abundant slump structures in Lower Miocene sediments, both features being indicators of slope instability at that time. Final termination of most of the structural movement on the ridge can be deciphered from the seismic records. There it is marked by a "smooth" reflector (see further discussion in Chapter 7) which can be seen on Figure 9, Plate 1. The sediments above this reflector are seen to be flat-lying, undeformed, and resting unconformably on the underlying dipping strata. This reflector is time-transgressive, as it can be seen to be overlain by successively younger strata at higher elevations. This behavior is evidenced on the profiler records of 0845 to 0945,31 March 1972. There it will be noted that older flat-lying strata exist at ridge elevations below that of Site 223. At this site, the reflector is believed to correspond to 
Lower Miocene sediments. Thus, relative ridge stability must have developed before then. An indication as to when this occurred is the initial appearance of slump features, which are found in Upper Oligocene sediments.

Dating the beginning phase of structural uplift is even more difficult because its initial effects would have been barely perceptible. However, indications of this effect can be seen as the tracing of the sedimentary history of Site 223 is resumed. Assuming that the CCD level changed but little in the Arabian Sea during Paleogene time, (a valid assumption based on the discussions relating to Sites 219 to 221), some shallowing of water depth is indicated for the Middle Eocene sediments. There, the amount of nannofossils increases to 20 percent from just a few percent in the underlying Lower Eocene sediments. The value for the sedimentation rate shows that this increase is not just due to a decrease in the rate of influx of other constituents. The same cannot be said for Upper Eocene to Upper Oligocene sediments. There, a continual increase in nannofossils, which reaches 85 percent in the youngest sediments, seems to be partially related to a decrease in detrital grains (again when the sedimentation rate is examined). This decrease could result from an elevation of the depositional site above the level of the basin floor such that bottom water nepheloid layers would no longer affect the site. This raising of the site, which would also expose it to stronger current action, may also account for the three unconformities present in Middle and Upper Eocene sediments. Part of the decrease in detrital grain influx, at least during Oligocene time, may also be related to what appears to have been extensive transgression of surrounding land areas (see Chapter 8). The Oligocene sediments reflect the decrease in detrital constituents by their nearly pure white color, an attribute also noted for similar aged sediments at Sites 219 and 220, and to some degree at Site 221.

A continuation of the trend toward a shallowing water depth after Middle Eocene time is seen by the improved state of preservation of the foraminifer, which culminates in a well-preserved and diverse planktonic foraminiferal assemblage in Oligocene sediments.

Recapitulating the preceeding data, it appears that the development of the Owen Ridge could have begun in Middle Eocene time although it may not have reached the degree of prominence seen today until Late Oligocene time. Structural growth during this period may have been continuous or spasmodic.

The sedimentation accompanying the structural activity was dominated by pelagic processes resulting in the formation of mostly nannofossil chalks. Siliceous fossils are rare in this interval being found mostly in the Middle Eocene portion of the stratigraphic record. Originally, however, they were much more common as shown by the abundance of cristobalite spherules (see Matter, this volume) and what appear to be relict radiolarian structures on smear slides. One can therefore show that the Middle and Early Eocene period of siliceous fossil generation in the southeastern Arabian Sea extended to the northern and western part of this basin as well.

The assemblage of clay minerals provides a further insight into depositional processes active at this site. Montmorillonite, which is prominent in Paleocene and
Eocene sediments, shows a significant reduction by Early Miocene time, indicating a decreasing contribution from volcanic sources. Upper Oligocene sediments are the first to display a small amount of the typical high ratio illite to chlorite clays of the Indus River, a period which coincides closely with its introduction by marine currents to Sites 219 through 221 in the southeastern Arabian Sea. The amount of palygorskite increases in the younger strata thereby varying inversely to the montmorillonite content. This suggests a secondary detrital origin for the palygorskite rather than a primary authigenic genesis. Again, as in the southeastern Arabian Sea, eolian transport over the western Arabian Sea appears to be the most likely source for this mineral.

Following this phase of pelagic draping of sediments on a ridge flank setting, a new style of sedimentation developed at Site 223. Flat-lying basinal deposition now took place in a feature called the Owen Basin (see Chapter 6). This basin was essentially developed by the uplift of the Owen Ridge. Apparently, during the early history of this basin, the Owen Ridge served as a barrier between it and the much deeper Arabian Basin to the east. (It must be remembered that at that time, 1300 meters or more of Indus Cone terrigenous debris now present, just to the east of the Owen Ridge in the Arabian Sea had not yet been deposited.)

Deposition in this basin from Middle Miocene time through to the Pleistocene consists mostly of fine-grained pelagic and terrigenous sediments although occasional coarse-grained turbidites are also present. One such turbidite is quite prominent in the upper part of the Middle Miocene. There, it coincides depthwise with a prominent "thin" reflector seen at this site (also see Chapter 7). Another coarse turbidite is seen in the Pleistocene section. Both are rich in shallow-water biogenous clastics which indicates derivation from a nearby continental shelf source rather than the Indus Delta.

The manner of basin filling which took place during this period appears to have been one that was largely controlled by horizontally layered gravity sedimentation. In addition to the sand turbidites, another technique of gravity emplacement is represented by a thick Upper Miocene slump breccia deposit. A gravity emplaced origin for the remaining, mostly fine-grained deposits, is not as obvious. Perhaps some are of turbid layer origin. That grain-by-grain emplacement of pelagic constituents was also a contributing mechanism at this time is emphasized by a significant admixture of nannofossils. Some idea of the relative importance of the two mechanisms can be gained by comparing the sedimentation rate at this site with that at Site 224 where only grain-by-grain sedimentation was taking place. This comparison shows a rate of $30 \mathrm{~m} / \mathrm{m}$.y. at Site 224 versus rates ranging from 60 to $180 \mathrm{~m} / \mathrm{m}$.y. at Site 223.

The biogenous admixture at Site 223, although consisting mostly of calcareous fossils, also contains a significant proportion of radiolarians in parts of the Middle and Upper Miocene section. Lesser amounts persist in younger strata. Whitmarsh (this volume) presents evidence for upwelling at this site since late Middle Miocene time. The upwelling probably reflects the beginning of monsoonal conditions in the Arabian Sea. 
Accompanying the siliceous organisms is an obvious lamination of the sediments, an increase in organic carbon content, pyrite development, and a color change from white to varying shades of green and gray. This association of features is more prevalent in deeper portions at this interval. It may relate not only to periodic high surface productivity but also to reducing conditions in the sediments which most likely were more intense when the Owen Basin initially developed. At that time, the Owen Ridge probably acted as a sill between the Owen and Arabian basins. Later sedimentation has served to erase this sill by gradually burying lower parts of the ridge. This is graphically displayed on the seismic track spanning the period 1000 to 1900,4 April 1972, where a zigzag course of the Glomar Challenger along the Owen Ridge resulted in a crossing of this feature along one of its spill points (see Figure 4, Plate 1). As this record shows, both basins now have filled to a common level in at least one place.

Limited X-ray mineralogy data indicate that Indus River clays constitute nearly half of the fine terrigenous sediments in the upper sediment interval. Much of the remainder is palygorskite of presumed eolian origin.

This entire later sediment sequence, in spite of large eolian and pelagic biogenous contributions, more nearly resembles a terrigenous than a pelagic deposit. High sedimentation rates locally exceed those seen at Site 221 on the Arabian Abyssal Plain. The Pleistocene sedimentation rate at Site 223 is even higher than that for Site 222 on the Indus Cone.

\section{Site 224}

Interpreting the geologic history of this site cannot be done with the same degree of refinement as for the previous site because of the long drilled intervals between cores and poor recovery. In addition, as a time-saving measure, the core barrel remained open during the drilling process resulting in sediment recovery which is not necessarily representative of the interval cored. Nevertheless, some stratigraphically pertinent conclusions can be made of the 792-meter stratigraphic section penetrated.

As at the previous site, the basic igneous rocks at the bottom of the hole are not typical of those formed at mid-ocean ridges. Consequently, postulating a water depth figure based on average ridge crest elevation cannot be done. However, there are diverse and well-preserved assemblages of nannofossils and planktonic foraminifera in the Middle and Lower Eocene sediments above the basalt. This indicates deposition above the CCD level at that time. Initial volcanic activity in the area is suggested by a basal layer of red montmorillonitic clay containing abundant palygorskite and cristobalite. The palygorskite probably has an authigenic origin. The cristobalite, though it may have developed from the alteration of volcanic glass, may also represent diagenetic replacement of siliceous fossils. Above this layer is a nannofossil-rich interval indicating a more prominent contribution from biogenous productivity. The rate of accumulation of all these sediments was only 10 $\mathrm{m} / \mathrm{m} . \mathrm{y}$.

Beginning in Late Eocene time, a change in sedimentation occurred. The nannofossils and foraminifera indicate a deepening such that water depths were near or below the CCD level. On the basis of the paleontological evidence, deep-water conditions persisted until Early Miocene time. During this period, the sedimentation rate at this site began to increase appreciably and by the Middle Oligocene had reached $100 \mathrm{~m} / \mathrm{m} . \mathrm{y}$. The site apparently was then situated on a basin floor. Mostly terrigenous deposits accumulated, including many sand beds, some of which exhibit good graded bedding. A turbidity current mechanism is indicated for their emplacement.

Prior to the Late Oligocene, the sedimentation rate was appreciably slower, and the clay minerals were dominated by montmorillonite until the Middle Oligocene. Some palygorskite is found in the older part of this sequence, but it was not noted in the more rapidly deposited sediments. Apparently, the high sedimentation rate effectively masks any evidence of eolian deposition during this period.

A change to relatively shallower water conditions accompanied by a decrease in the sedimentation rate occurred in Middle or Early Miocene time. This change presumably reflects uplift along the Owen Fracture Zone. No longer was the site a basinal depositional area, but it now occupied a crestal ridge position. Because of this, the depositional style changed from terrigenous accumulation of probably flat-lying beds to topographic draping by pelagic materials. The shallower water depths allowed for a greater accumulation of biogenous sediments, including mostly nannofossils. Foraminifera exhibit a better preserved and more diverse fauna and significant amounts of Radiolaria appear in Late Miocene and younger strata. The same effects of monsoonal upwelling noticed at Site 223 extend to this site as well. The slower accumulation of sediments (now $30 \mathrm{~m} / \mathrm{m} . \mathrm{y}$.) allowed eolian sediments to become more prominent, and now palygorskite is an important constituent.

The steep crestal ridge location of Site 224 created the same conditions of slope instability noted at Site 223. An examination of the seismic profiler record (see Figure 4, Plate 1, 2000 to $2200 \mathrm{hrs)}$ shows that a thick layer of sediment has been removed by slumping from the backslope of the ridge, leaving only a remnant at the crest. This layer represents sediments deposited before approximately Late Pleistocene and after Late Miocene time.

In many ways Sites 223 and 224, although both are along the Owen Ridge, have strongly differing sedimentary histories. Thus, while the former occupied a ridge setting in Paleogene time, Site 224 had a basinal location. During the Neogene these relationships were reversed. Part of the reason for this antithetic behavior is because of differing structural histories and part is due to the sites being situated at differing distances from the Owen Fracture Zone.

\section{SUMMARY}

1. On the basis of the presence or absence of Deccan Trap detritus (i.e., montmorillonite), some conclusions concering the history of the Indian Peninsula can be made. During an earlier part of the Late Paleocene, this peninsula apparently was strongly emergent. At the very end of Paleocene time, it became largely submergent, a condition which persisted till the Middle Miocene. It then rose above sea level, an aspect it has retained to the present. 
2. Sites 220 and 221 both reflect an initial sedimentary history tied largely to that of typical oceanic rise generated crust which, because of lithospheric cooling, sinks from deep water into still greater depths as it travels from the ridge crest. As such, Site 221, and probably 220, developed a "normal pelagic sequence" of biogenous ooze overlain by brown clay.

3. An eolian contribution to Arabian Sea sedimentation can be identified in all but the rapidly sedimented turbiditic intervals. This contribution is particularly prominent on the western side. As such, this geographic distribution coincides with findings by others on Recent sediments.

4. The Indus River first became an important contributor to deep-sea sediments in Middle or Late Oligocene time. This date may reflect when the collision of the Asian and Indian Plates first resulted in prominent uplift of the Himalayas. Alternately it may simply mean that this was when the proto-Indo-Gangetic Plain was first able to prograde to the western Indian Coast and there influence Arabian Sea sedimentation.

5. The Indus Cone and Arabian Abyssal Plain are not solely the product of the Indus River. A fairly substantial input of calcareous turbidites was provided by the western Indian shelf during Plio/Pleistocene time. The latter material locally constitutes up to half of the turbidite sediments of the eastern part of the Arabian Abyssal Plain.

6. A Middle and Early Eocene period of siliceous fossil deposition appears to characterize much of the Arabian Sea. This deposition has led to the development of a prominent chert reflector layer in the southern Arabian Sea.

7. Upwelling in the western Arabian Sea began in Middle Miocene time. This may reflect the initial development of a monsoonal current system in this body of water.

8. The distribution of white biogenic oozes at Sites 219 , 220,221 , and 223 suggests that much of the land area bordering the Arabian Sea was submerged from Middle or Late Eocene to Middle Miocene time. An exception to this would be uplift in the Himalayan region.

9. Uplift of the Owen Ridge near Site 223 apparently was completed by Late Oligocene time. At Site 224, uplift of this feature seemingly did not occur until Middle or Early Miocene time.

10. The sedimentation pattern at Sites 220 and 221 suggests that a rise in the CCD occurred during later Miocene or Pliocene time.

11. The total contribution of the turbidite mechanism to sedimentation on the Indus Cone was difficult to judge. Most of the muds which dominate the stratigraphic section lack structures commonly assigned to finer-grained turbidites. Turbid layer transport or a deep nepheloid layer may have played an important part in their deposition.

The preceding summary review of the sedimentary history of Sites 219 through 224 provides several significant conclusions bearing on the stratigraphy of the Arabian Sea. The reader will recognize that some of these are well-documented whereas others are more in the way of speculations. Both types are useful as they point out where later studies may further refine the history of the Arabian Sea as well as that of the surrounding land areas.
Particularly pertinent here is the data uncovered at Site 219 and, to a lesser extent, Sites 220 and 221 . This data reflects directly on the behavior of the Indian Peninsula which in turn relates to the collision of the Indian and Asian Plates and to the formation of the Arabian Sea. Closer examination of marine strata and of their clay mineralogy in wells drilled along the west coast of India, should provide particularly useful information on this subject.

\section{REFERENCES}

Berger, W. H., 1972. Deep sea carbonates: dissolution facies and age-depth constancy: Nature, v. 236 , no. 5347 , p. 392-395.

Bszrukov, P. L., 1961. Investigations in the Indian Ocean on the 33rd cruise of the expeditionary vessel Vityaz: Okeanologiya, v. 1, no. 4, p. 745-753.

Defant, A., 1961. Physical oceanography: New York, London (Pergamon Press), p. 598.

Düing, W., 1970. The Monsoon regime of the currents in the Indian Ocean: Honolulu (East-West Cent. Press), p. 68.

Fairbridge, R. W., Heezen, B. C., Ichiye, T., and Tharp, M., 1966. Indian Ocean. In Fairbridge, R. W., (Ed.), The encyclopedia of oceanography: New York (Reinhold Publishing Corp.), p. 370-402.

Förstner, U., 1971. Geochemische-Sedimentpetrographische Untersuchungen an den Endseen und anderen Zuflussen in Afghanistan: Heidelberg (Habilitationgschrift Univ.), p. 122.

Goldberg, E. D. and Griffin, J. W., 1970. The sediments of the northern Indian Ocean: Deep Sea Res., v. 17, p. 513-537.

Hathaway, J.C. and Sachs, P. L., 1965. Sepiolite and clinoptilolite from the Mid-Atlantic Ridge: Am. Min., v. 50, p. 852 .

Holeman, J.H., 1968. The sediment yield of the major rivers of the world: Water Resources Res., v. 4, p. 737-747.

Laughton, A. S., Whitmarsh, R. B., and Jones, M. T., 1970. The evolution of the Gulf of Aden: Roy. Soc. London Phil. Trans., Ser. A, v. 267, p. 227-266.

Lisitzin, A. P., 1972. Sedimentation in the world ocean: Soc. Econ. Paleont. Min., Spec. Publ., no. 17, p. 218.

McKenzie, D. P. and Sclater, J. G., 1971. The evolution of the Indian Ocean since the Late Cretaceous: Roy. Astron. Soc. Geophys. J., v. 25, p. 437-528.

Moore, D. G., 1966. Structure, litho-orogenic units and postorogenic basin fill by reflection profiling: California continental borderland: Phd. Dissert., Univ. Groningen, p. 151 .

Muller, G., 1961. Palygorskite and sepiolith in Tertiären and Quartären Sedimenten von Hadramawt (S. Arabian): Neus Jb. Min., v. 97, p. 275-288.

Neprochnov, Yu. P., 1961. Sediment thickness of the Arabian Sea Basin (in Russian): Dokl. Akad. Nauk., v. 139 (1), p. 177-179.

Schott, G., 1935. Geographie des Indischen und Stillen Ozeans: Hamburg (Boysen), p. 413.

Schott, W., 1966. Recent sedimentation in the Indian Ocean first results of "Meteor" Indian Ocean Expedition: Bundes. für Bodenforsch., HannoverBuchholz, Alfred-Bentz, Germany, p. 424-427.

Shepard, F. P. 1963. Submarine geology: New York, Evanston and London (Harper \& Row), 557 p. 
Stackelberg, U. V., 1972. Faziesverteilung in Sedimenten des. Indisch-Pakistanischen Kontinentalrandes (Arabisches Meer): "Meteor", Forsch.-Ergeb. Reihe C., no. 9, p. 1-73.

Stewart, R. A., Pilkey, O. H., and Nelson, B. W., 1965. Sediments of the northern Arabian Sea. In Marine Geol., New York (Elsevier Publ), no. 3, p. 411-427.

Sugden, W., 1963. Some Aspects of sedimentation in the Persian Gulf: J. Sediment, Petrol., v. 33, no. 2, p. 355-364.
Wadia, D. N., 1968. The geology of India: New York, London (MacMillan and Co. Ltd.), p. 526.

Wyrtki, K., 1971. Oceanographic atlas of the international Indian Ocean Expedition: Washington (U. S. Government Printing Office), p. 531.

Zobel, B., 1973. Biostratigraphische Untersuchungen an Sedimenten des indisch-pakistanischen Kontinentalrandes (Arabisches Meer): "Meteor", Forsch.-Ergeb. Reihe C., 12, p. 9-73. 